ISSN 1392-3196 / e-ISSN 2335-8947

Zemdirbyste-Agriculture, vol. 107, No. 2 (2020), p. 131-138

DOI 10.13080/z-a.2020.107.017

\title{
Assessment of toxicity impacts of chemical protection of winter wheat, sugar beet and winter rape on aquatic ecosystems and humans
}

\author{
Małgorzata HOLKA, Jerzy BIEŃKOWSKI \\ Polish Academy of Sciences, Institute for Agricultural and Forest Environment \\ Bukowska 19, 60-809 Poznań, Poland \\ E-mail: malgorzata.holka@isrl.poznan.pl
}

\begin{abstract}
The study aimed to assess the potential toxicity impacts of the application of plant protection products on aquatic ecosystems and humans. The analysis was based on the data on chemical protection of winter wheat (Triticum aestivum L.), sugar beet (Beta vulgaris L.) and winter rape (Brassica napus L.) collected in Trzebiny Agricultural Farm, located in Wielkopolska voivodeship, Poland. Routes and amounts of environmental emissions were determined using the model PestLCI 2.08. These results constituted inventory data in the studies by the life cycle assessment (LCA) method. The characterization model USEtox 2.02 was used to assess the freshwater ecotoxicity potential (FETP) and the human toxicity potential (HTP), including carcinogenic and noncarcinogenic effects. Among the analysed agricultural crops, the largest consumption of the active substances was noted in the protection products of sugar beet $\left(7.43 \mathrm{~kg} \mathrm{ha}^{-1}\right)$, followed by winter wheat $\left(2.64 \mathrm{~kg} \mathrm{ha}^{-1}\right)$ and the lowest was for winter rape $\left(2.16 \mathrm{~kg} \mathrm{ha}^{-1}\right)$. Assessment of environmental emissions from plant protection showed that the largest amounts of active substances were available for leaching and surface runoff (average $91.7 \%$ of overall emissions). Emissions to the air and groundwater were smaller (on average $7.7 \%$ and $0.6 \%$, respectively). There were no significant differences in the FETP impact among the analysed plants. The greatest threat to human (h) health resulted from chemical protection of sugar beet $\left(1.7 \mathrm{E}-05\right.$ comparative toxic unit $\left.(\mathrm{CTU}) \mathrm{h} \mathrm{ha} \mathrm{h}^{-1}\right)$, while the lowest value of the HTP impact was noted in the protection products of winter rape (3.3E - $\left.06 \mathrm{CTUh}^{-1}\right)$. The results showed that the total freshwater ecotoxicity and human toxicity impacts were associated with physicochemical properties and toxicity of individual active substances. To more comprehensively evaluate the potential effects of plant protection products, a diverse range of active substances available for application should be considered.
\end{abstract}

Key words: active substances, environmental emissions, freshwater ecotoxicity, human toxicity.

\section{Introduction}

Plant protection products (PPPs) affect the yield and quality of agricultural crops and therefore are one of essential elements of plant production technology. The use of chemical PPPs is relatively cheap, easy and very effective at reducing crop losses caused by diseases and pests. However, intensive and, above all, improper use of PPPs can lead to environmental and health threats. Active substances in PPPs used volatilize into the air, drain into the surface water and leak into the groundwater (Żak, 2016). They can also accumulate in the tissues of living organisms. Like other chemicals, they enter human and animal bodies through inhalation contact with the skin and eyes as well as through ingestion of food and water containing residues of PPPs (Fantke, Jolliet, 2016). Studies show that some of the metabolites formed by transformation of active substances are more toxic to organisms than the parent compound (Kot-Wasik et al., 2003). Toxic effects of chemical plant protection are wide ranging and depend on many factors, including the quantity of the chemical absorbed by an organism, exposure, toxicity of the substance, its chemical form, volatility, solubility in body fluids and lipids as well as on the immunity of the specific organism (Kim et al., 2017). It can cause both immediate acute poisoning and chronic diseases. This is often a long-term systematic influence at relatively low doses of toxicants (Mahmood et al., 2016). Scientific research findings confirm the relationship between exposure to active substances and the risk of cancer diseases; hence, some substances are classified as carcinogenic chemicals (Parrón et al., 2014).

The choice of PPPs containing active substances with different physico-chemical properties and toxicity has a significant role for environmental effects of plant protection (Houdart et al., 2009; Holka, 2017). Therefore, an assessment should not be limited to the consumption of active substances. Multi-criteria and reliable analysis

Please use the following format when citing the article:

Holka M., Bieńkowski J. 2020. Assessment of toxicity impacts of chemical protection of winter wheat, sugar beet and winter rape on aquatic ecosystems and humans. Zemdirbyste-Agriculture, 107 (2): 131-138. DOI 10.13080/z-a.2020.107.017 
can be performed using life cycle assessment (LCA) methodology. This method identifies the potential impacts of environmental and health in the life cycle of process, product or service, allowing one to determine ways to reduce their impact (Caffrey, Veal, 2013).

The aim of this study was to assess and compare the impact potentials of the application of plant protection products (PPPs) for human toxicity and ecotoxicity in the production of winter wheat, sugar beet and winter rape.

\section{Materials and methods}

Description of the study site. The analysed data on chemical protection treatments of winter wheat, sugar beet and winter rape were collected in 2012-2015 in Trzebiny Agricultural Farm, located in Wielkopolska voivodeship, Poland. The studied farm has a total area of 492 ha of agricultural land and runs intensive agricultural production. Cereals accounted for on average $61.1 \%$ of the total sown area of the farm. The other important plant group with a large share of sown area (20.8\%) were industrial crops, including root and oilseed crops. The annual and perennial fodder crops were cropped on $18.1 \%$ of the cultivated area. The farm is also a milk producer. It has a herd of 200 dairy cows, producing nearly 2 million litres of milk per year.

Life cycle assessment (LCA) methodology. The potential impact of chemical plant protection on the environment and human health was examined using the LCA method, which is divided into four phases: 1) goal and scope definition, 2) inventory analysis, 3) impact assessment and 4) interpretation. The $1^{\text {st }}$ phase of the LCA method involves determining the purpose of the research, the system of assessed product or process, the system boundaries and a functional unit. The $2^{\text {nd }}$ phase is the collection of input and output data in relation to the functional unit of the Life Cycle Inventory (LCI) system. Inventory data are necessary for performing the Life Cycle Impact Assessment (LCIA). This $3^{\text {rd }}$ phase includes three mandatory steps: selection of impact categories, category indicators and characterization models, classification and characterization. The relevant impact categories should be selected, which address the identified environmental issues and concerns. During the classification, the inventory data are assigned to a particular impact category. The characterization aims to calculate the category indicator results using the characterization factors and models. In the $4^{\text {th }}$ (interpretation) phase, the results of the analysis are evaluated in terms of consistency, completeness and robustness, and the conclusions are drawn according to the purpose of the research (Brentrup et al., 2004).

The LCA method conducted here focused on the assessment of the toxicity impacts of the application of chemical plant protection for the cultivation of three agricultural crops: winter wheat (Triticum aestivum L.), sugar beet (Beta vulgaris L.) and winter rape (Brassica napus L.). The system boundaries were set at the field gate, so the production of plant protection products (PPPs), manufacture and use of machinery, fuel production and combustion were outside these boundaries. It should be noted that although these processes also affect the environment, emission from application of PPPs is considered to be the major contributor to toxicity impacts in LCA method of conventional agricultural products. The functional unit was 1 hectare of cultivated area.
Inventory analysis. The amount of each active substance applied on the agricultural field was considered in the LCI system as the input from the anthropogenic system, i.e. the technosphere. In turn, the emissions of particular substances from plant protection to the environment (the ecosphere) were recognized as the outputs. Emissions from PPPs were calculated using an updated version of the model PestLCI 2.08, which is made available for use by running the software Analytica (Lumina Decision Systems, Inc.). The model takes into account such data as the type of the active substance, soil and climatic conditions, a month, a method of application, the crop species and crop growth stage, dimensions of field, field slope, annual irrigation and soil tillage system. The technosphere is regarded as the air column above the field up to a height of $100 \mathrm{~m}$ and the soil to $1 \mathrm{~m}$ depth. The model PestLCI 2.08 calculates emissions of active substances to three environmental compartments: air, surface water and groundwater (Birkved, Hauschild, 2006; Dijkman et al., 2012). It was calibrated to the research conditions by loading local climate and soil data. In addition, the database was expanded to include information about physico-chemical and toxicological properties of active substances used locally in the studied farm, which have not been present in the generic version of the model database. Data sources for the chemical properties of active substances were online databases (EU Pesticides Database, 2018; PPDB, 2018) and the Estimation Program Interface (EPI Suite, 2018).

Ecotoxicity and human toxicity impacts. LCIA of chemical plant protection was conducted for the ecotoxicity and human toxicity impact categories. Within the ecotoxicity category, the freshwater ecotoxicity potential (FETP) impact was calculated, which determines an estimated fraction of species potentially affected by environmental stress and is expressed in the comparative toxic unit for ecotoxicity (CTUe) (Henderson et al., 2011). In the case of the human toxicity impact category, the human toxicity potential (HTP) impact was considered. The HTP impact includes two components: the HTP for carcinogenic (HTP cancer) and non-carcinogenic (HTP non-cancer) effects. Human toxicity impacts determine an estimated increase in morbidity in the total human population per unit mass of a contaminant (number of disease cases per $1 \mathrm{~kg}$ of emitted substance) and are measured in comparative toxic unit for human (h) health (CTUh) (Rosenbaum et al., 2011).

The model USEtox 2.02 recommended by the Life Cycle Initiative of the United Nations Environment Program (UNEP) and the Society for Environmental Sciences and Chemistry (SETAC) (https://usetox.org/) was used to characterize human toxicity and ecotoxicity impacts in life cycle assessment of plant protection. It is implemented in Microsoft Excel spreadsheets and works with an integrated database providing a set of substance-specific input data in the following areas: physico-chemical properties, toxicological effect on laboratory animals and humans and ecotoxicological effect on freshwater organisms (Rosenbaum et al., 2008; Hauschild et al., 2016). The model performs matrix calculations to obtain the characterization factor $(\mathrm{CF})$ value of the substance, depending on its environmental routes of emissions for the FETP and HTP impacts. Each $\mathrm{CF}$ is calculated by multiplying a fate factor (FF) by an exposure factor (XF) and by an effect factor 
(EF). Considering the characterization process for the FETP impact, both the FF (expressed in days) and XF (dimensionless) result from physico-chemical properties of the substance and the processes that occur in the environment. The EF is estimated on the basis of the values of chronic hazardous concentration for the substance (HC50) calculated as the arithmetic mean of all logged geometric mean values of half lethal (LC50) or half maximum effective (EC50) concentrations for different taxonomic groups at different trophic levels. It is expressed in potentially affected fraction (PAF) of species integrated over the exposed water volume $\left(\mathrm{m}^{3}\right)$ per kilogramme of the substance emitted into the environment (PAF $\mathrm{m}^{3} \mathrm{~kg}^{-1}$ ). Ultimately, the $\mathrm{CF}$ of the substance obtained for freshwater ecotoxicity reflects changes in potentially affected fraction of freshwater species integrated over exposed volume and time per $\mathrm{kg}$ of the substance (PAF $\mathrm{m}^{3}$ day $\mathrm{kg}^{-1}$ ) (Saouter et al., 2017). In the impact assessment for human health, calculations of the FF are performed in the same way as for the freshwater ecotoxicity impact. The XF takes into account the risks associated with the intake and inhalation exposure of substances. The EF is related to human effects and expresses the change in the probability of diseases depending on the substance collection (cases of disease per $\mathrm{kg}$ of substance). Characterization factors are reported separately for carcinogenic and noncarcinogenic effects (Rosenbaum et al., 2011).

To calculate the values of the FETP and the HTP, the mass of each substance emitted to a particular environmental compartment is multiplied by its characterization factor, according to the following formula (Rosenbaum et al., 2008):

$$
I_{\text {score }}=\sum_{i}\left(m_{i, x} \times C F_{i, x}\right)
$$

where $\mathrm{I}_{\text {score }}$ is the impact category indicator, $\mathrm{m}_{\mathrm{i}, \mathrm{x}}$ the emitted mass of substance $i$ to the compartment $x$ ( $(\mathrm{kg}$ $\left.\mathrm{d}^{-1}\right), \mathrm{CF}_{\mathrm{jx}}-$ the characterization factor of the substance $i$ released to the compartment $x\left(\mathrm{CTUe} \mathrm{kg}^{-1}\right)$.

Statistical analysis. The data were processed by the analysis of variance (ANOVA) using the software Statistica, version 8 (StatSoft Inc., USA). Significant differences between data were determined using Tukey's test at the 0.05 probability level. The results were expressed as means and standard deviations of the means.

\section{Results and discussion}

The study showed that the largest number of chemical treatments was carried out in the sugar beet crop (5.9), followed by winter rape (4.4) and winter wheat (3.5) (Fig. 1). In protection of winter wheat and sugar beet, herbicide treatments were dominant (accounting for $30.1 \%$ and $80.1 \%$, respectively), followed by fungicide treatments $(31.0 \%$ and $19.9 \%$, respectively). In addition to this, protection of winter wheat was characterized by a larger share of treatments using plant growth regulators $(21.4 \%)$, while the share of insecticide treatments was lower than noted in any other crop (9.5\%). In winter rape, the most frequent were fungicide treatments $(40.8 \%)$, whilst herbicide and insecticide treatments were also important for the plant protection of this crop $(31.2 \%$ and $25.4 \%$, respectively). The lowest share was for treatments with plant growth regulators $(2.6 \%)$.

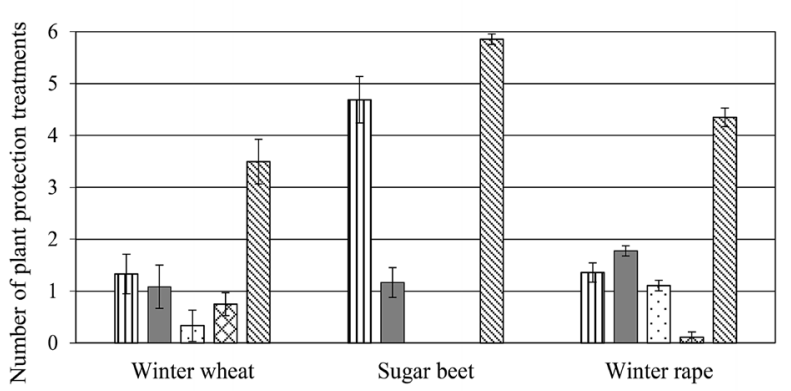

巴Herbicides $\square$ Fungicides $\square$ Insecticides $\otimes$ Plant growth regulators $₫$ Total

Figure 1. Number of plant protection treatments in the analysed agricultural crops (mean for 2012-2015 \pm standard deviation)

Table 1 presents the results of the inventory analysis of chemical protection of the analysed agricultural crops. In terms of the consumption of active substances, the highest intensity of chemical protection was observed in sugar beet $\left(7.43 \mathrm{~kg} \mathrm{ha}^{-1}\right)$, followed by winter wheat $\left(2.64 \mathrm{~kg} \mathrm{ha}^{-1}\right)$ and winter rape $\left(2.16 \mathrm{~kg} \mathrm{ha}^{-1}\right)$. Regarding the structure of consumption of PPPs, the largest share had herbicides (from $38.0 \%$ in winter wheat to $96.7 \%$ in sugar beet), followed by fungicides (from $32.1 \%$ in winter rape to $38.0 \%$ in winter wheat). Lower consumption of active substances was recorded for insecticides (from $10.6 \%$ in winter wheat to $13.4 \%$ in winter rape) and plant growth regulators (from $5.6 \%$ in winter rape to $13.4 \%$ in winter wheat). The total amount of environmental emissions of active substances calculated using the model PestLCI 2.08 was the highest in the chemical protection of sugar beet $\left(3.99 \mathrm{~kg} \mathrm{ha}^{-1}\right)$, in winter wheat it was lower by $68.9 \%$. Less emission from the application of PPPs was noted in winter rape $\left(0.47 \mathrm{~kg} \mathrm{ha}^{-1}\right)$. The emission structure according to the routes of environmental compartments was similar for all crops analysed. The largest streams of emissions were constituted by the amounts of active substances available for leaching and surface runoff (from $83.7 \%$ in winter wheat to $97.4 \%$ in sugar beet). The share of air emissions ranged from $2.1 \%$ in sugar beet to $15.5 \%$ in winter wheat. In turn, emissions to groundwater did not exceed $1 \%$ of the overall emission in each of the analysed agricultural crops.

Among the types of PPPs, the herbicides had the highest environmental emissions (Fig. 2). Their emissions constituted from $51.5 \%$ to $85.7 \%$ of the overall emission of active substances to the air, from $93.4 \%$ to $96.6 \%$ of emission to the groundwater and from $45.5 \%$ to $99.2 \%$ of the total amount of substances available for leaching and surface runoff. A significant share in the environmental emissions came from fungicides, which caused $10.8 \%$ to $39.3 \%$ of emissions to the air, $0.4 \%$ to $5.0 \%$ of emissions to the groundwater and $0.8 \%$ to $33.7 \%$ of the amount of substance available for leaching and surface runoff. It was also found that the application of insecticides in the plant protection of winter rape contributed to $21.1 \%$ of emissions to the air and $12.5 \%$ of the amount of substance available for leaching and surface runoff. In turn, the application of plant growth regulators was mainly related to the amount of substance available for leaching and surface runoff. The share of that stream of emissions was highest for winter wheat and winter rape (9.8\% and $8.2 \%$, respectively). 
Table 1. Inventory data of a set of the main inputs and outputs in relation to 1 ha of plant protection products applied in the analysed agricultural crops (mean for 2012-2015)

\begin{tabular}{|c|c|c|c|c|c|c|c|}
\hline \multirow[t]{2}{*}{ Specification } & \multirow[t]{2}{*}{ Unit } & $\begin{array}{l}\text { Winter } \\
\text { wheat }\end{array}$ & $\begin{array}{c}\text { Sugar } \\
\text { beet }\end{array}$ & $\begin{array}{c}\text { Winter } \\
\text { rape }\end{array}$ & $\begin{array}{l}\text { Winter } \\
\text { wheat }\end{array}$ & $\begin{array}{c}\text { Sugar } \\
\text { beet }\end{array}$ & $\begin{array}{c}\text { Winter } \\
\text { rape }\end{array}$ \\
\hline & & \multicolumn{3}{|c|}{ mean } & \multicolumn{3}{|c|}{ standard deviation } \\
\hline \multicolumn{8}{|c|}{ Inputs } \\
\hline Consumption of active substances, of which: & $\mathrm{kg} \mathrm{ha}^{-1}$ & 2.64 & 7.43 & 2.16 & 0.46 & 2.18 & 0.66 \\
\hline herbicides, & $\mathrm{kg} \mathrm{ha}^{-1}$ & 1.00 & 7.19 & 1.06 & 0.47 & 2.22 & 0.36 \\
\hline fungicides, & $\mathrm{kg} \mathrm{ha}^{-1}$ & 1.00 & 0.24 & 0.69 & 0.36 & 0.07 & 0.12 \\
\hline insecticides, & $\mathrm{kg} \mathrm{ha}^{-1}$ & 0.28 & 0 & 0.29 & 0.14 & 0 & 0.09 \\
\hline plant growth regulators & $\mathrm{kg} \mathrm{ha}^{-1}$ & 0.35 & 0 & 0.12 & 0.32 & 0 & 0.21 \\
\hline \multicolumn{8}{|c|}{ Outputs } \\
\hline Crop yield & t ha $^{-1}$ & 7.35 & 62.58 & 3.29 & 1.28 & 7.53 & 0.68 \\
\hline \multirow{4}{*}{$\begin{array}{l}\text { Environmental emissions, of which: } \\
\text { emissions to air, } \\
\text { emissions to groundwater, } \\
\text { mass of substances available } \\
\text { for leaching and surface runoff }\end{array}$} & $\mathrm{kg} \mathrm{ha}^{-1}$ & 1.24 & 3.99 & 0.47 & 0.27 & 0.07 & 0.01 \\
\hline & $\mathrm{kg} \mathrm{ha}^{-1}$ & 0.19 & 0.08 & 0.03 & 0.01 & 0.005 & 0.001 \\
\hline & $\mathrm{kg} \mathrm{ha}^{-1}$ & 0.01 & 0.02 & 0.003 & 0.36 & 1.03 & 0.07 \\
\hline & $\mathrm{kg} \mathrm{ha}^{-1}$ & 1.04 & 3.89 & 0.44 & 0.4 & 2.34 & 0.56 \\
\hline
\end{tabular}

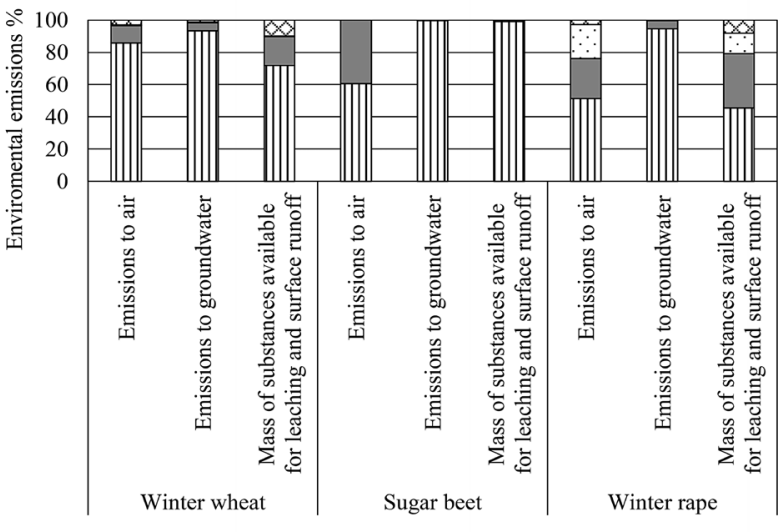

๓Herbicides घFungicides $\square$ Insecticides $\otimes$ Plant growth regulators

Figure 2. Percentage share of environmental emissions of active substances by type of plant protection products applied in the analysed agricultural crops (mean for 2012-2015)
The results of assessment of toxicity potential impacts of chemical plant protection calculated with reference to 1 ha of cultivated area are summarized in Table 2. The highest value of the FETP per ha, indicating the most toxic impact on freshwater ecosystems, was produced by winter wheat $(3.7 \mathrm{E}+03 \mathrm{CTUe})$. The lower threat was caused by the chemical protection of sugar beet and winter rape (by $62.2 \%$ and $73.5 \%$, respectively). However, the impact differences between the crops were not statistically significant. This paper reports much higher FETP impact in winter wheat compared to the results obtained by Nordborg et al. (2014) in Sweden (266 CTUe ha-1).

Results indicated that the HTP from the crop protection was significantly higher in sugar beet $(1.7 \mathrm{E}-$ $05 \mathrm{CTUh} \mathrm{ha}^{-1}$ ) (Table 2). Less negative potential impact on human health resulted from PPPs applied in winter wheat (lower by $66.9 \%$ ) and winter rape (by $80.7 \%$ ). The highest value of the HTP cancer impact was associated with the protection of sugar beet $\left(9.8 \mathrm{E}-06 \mathrm{CTUh} \mathrm{ha}^{-1}\right)$,

Table 2. Values of the freshwater ecotoxicity potential (FETP) and human toxicity potential (HTP) impacts per ha, resulted of chemical protection in the analysed agricultural crops (mean for 2012-2015)

\begin{tabular}{lcccc}
\hline \multicolumn{1}{c}{ Impact category indicator } & Unit & Winter wheat & Sugar beet & Winter rape \\
\hline FETP & CTUe ha $^{-1}$ & $3.7 \mathrm{E}+03 \mathrm{~ns}$ & $1.4 \mathrm{E}+03 \mathrm{~ns}$ & $9.8 \mathrm{E}+02 \mathrm{~ns}$ \\
HTP, of which: & CTUh ha $^{-1}$ & $5.6 \mathrm{E}-06 \mathrm{a}$ & $1.7 \mathrm{E}-05 \mathrm{~b}$ & $3.3 \mathrm{E}-06 \mathrm{ac}$ \\
$\quad$ HTP cancer, & CTUh ha $^{-1}$ & $2.8 \mathrm{E}-06 \mathrm{ab}$ & $9.8 \mathrm{E}-06 \mathrm{~b}$ & $8.1 \mathrm{E}-07 \mathrm{ac}$ \\
$\quad$ HTP non-cancer & CTUh ha $^{-1}$ & $2.8 \mathrm{E}-06 \mathrm{a}$ & $7.2 \mathrm{E}-06 \mathrm{~b}$ & $2.5 \mathrm{E}-06 \mathrm{ac}$ \\
\hline
\end{tabular}

Note. HTP cancer and HTP non-cancer - human toxicity potential for carcinogenic and non-carcinogenic effects, CTUe comparative toxic unit for ecotoxicity; within a row the means for individual plants marked by different letters are significantly different $(p<0.05)$; ns - no significantly different.

followed by winter wheat $\left(2.8 \mathrm{E}-06 \mathrm{CTUh}^{\mathrm{h}} \mathrm{a}^{-1}\right)$ and winter rape $\left(8.12 \mathrm{E}-07 \mathrm{CTUh} \mathrm{ha}^{-1}\right)$. Chemical protection of winter rape posed significantly lower carcinogenic threat to humans compared to sugar beet. The most harmful active substances for human health in terms of other than carcinogenic effect were applied in sugar beet (7.2E - 06 CTUh ha $\left.{ }^{-1}\right)$, followed by winter wheat $(2.8 \mathrm{E}$ - $\left.06 \mathrm{CTUh}^{-1}\right)$ and winter rape $\left(2.5 \mathrm{E}-06 \mathrm{CTUh} \mathrm{ha}^{-1}\right)$. The HTP non-cancer impact determined for sugar beet was significantly higher in comparison to winter wheat and winter rape.

Figure 3 shows that the value of the FETP impact in chemical protection of winter wheat and sugar beet was associated primarily with the application of herbicides (accounted for $67.3 \%$ and $79.5 \%$ of value of this indicator, respectively) and fungicides (32.5\% and $20.5 \%$, respectively). In contrast, in protection of winter rape this impact resulted mainly from the application of insecticides $(83.5 \%)$ and fungicides $(14.3 \%)$. The value of the HTP impact in the protection of winter wheat and sugar beet was determined by herbicides $(69.8 \%$ and $63.4 \%$, respectively) and fungicides $(18.5 \%$ and $36.6 \%$, respectively), whilst in winter rape protection it was insecticides (51.9\%) and fungicides (43.7\%). Among the types of PPPs applied in winter wheat and sugar beet, the highest potential carcinogenic effect were herbicides 


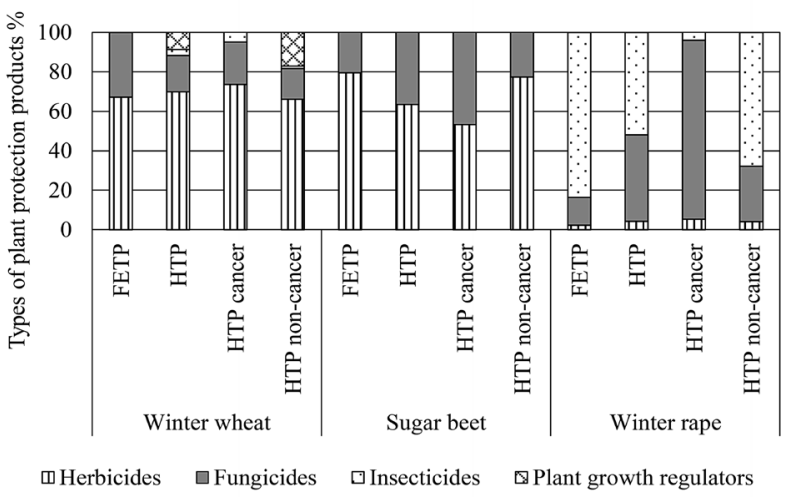

Explanations of abbreviations for toxicity impacts under Table 2

Figure 3. Percentage share of types of plant protection products in formation of the values of toxicity potential impacts of chemical protection in the analysed agricultural crops (mean for 2012-2015)

(73.6\% and $53.2 \%$, respectively), followed by fungicides ( $21.5 \%$ and $46.8 \%$, respectively). In winter rape, this impact depended primarily on fungicides $(90.6 \%)$. In the chemical protection of winter wheat and sugar beet, the most harmful for humans in terms of non-carcinogenic effect were herbicides $(66.0 \%$ and $77.3 \%$, respectively) and fungicides (15.7\% and $22.7 \%$, respectively), whilst in winter rape protection, insecticides had the highest toxicity $(67.6 \%)$, followed by fungicides $(28.2 \%)$.

In the production of refined sugar in Italy, it was also found that among types of PPPs applied in sugar beet, herbicides had the greatest impact on the FETP (Garavini et al., 2015). The life cycle assessment of wheat production in Italy showed that the value of the FETP impact (accounting for $67.3 \%$ ) depended mainly on the toxicity of the fungicides applied (Fantin et al., 2017).

It should be noted that the consumption of both herbicides and fungicides was low, amounting to only $0.04 \mathrm{~kg}$ and $0.38 \mathrm{~kg}$ of active substance per ha of cultivated area, respectively. It was assumed that emissions to the air and soil associated with chemical plant protection constituted $10 \%$ and $85 \%$, respectively, of the total amount of active substance applied. The approach adopted was developed by Margni et al. (2002). There are various methods proposed in the literature for estimating the emissions of active substances to the environment (Nemecek, Kägi, 2007; Neto et al., 2012). Therefore, divergences can be observed in the LCI system results. The more accurate data on the routes of emissions to the environment are critically important as they provide a basis for assessing the potential toxicity indicators by the LCA method (Rosenbaum et al., 2015). The model PestLCI 2.08, which takes into account many characters concerning physico-chemical properties of active substances and pedoclimatic conditions, is by now the most advanced tool for estimating the environmental emissions of active substances (Van Zelm et al., 2014).

Figure 4 presents the percentage share of the five most toxic active substances in formation of the FETP impact in LCA method of chemical protection of the selected plant species. Over $50 \%$ of the value of this indicator for sugar beet depended on the application of the herbicide lenacil and in the case of winter rape on the insecticide chlorpyrifos. In the protection of winter wheat, the herbicide pendimethalin had the greatest FETP $(38.2 \%)$.

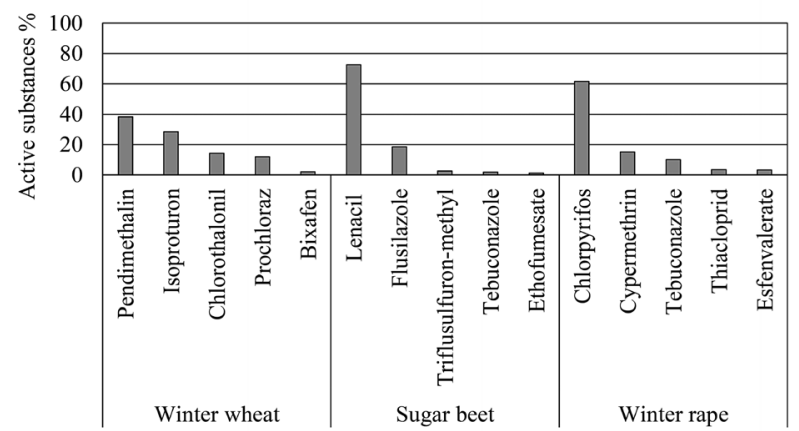

Figure 4. Percentage share of most toxic active substances with the largest contribution to the freshwater ecotoxicity potential (FETP) impact of chemical protection in the analysed agricultural crops (mean for 2012-2015)

Danish studies on environmental impacts associated with biomass production for biorefinery showed that the highest value of FETP impact was for winter wheat straw (31 CTUe ha $\left.{ }^{-1}\right)$. It should be noted that the consumption of PPPs as well as the emissions of active substances in the case of wheat were also greater as compared to maize, grass-clover and ryegrass. Similar to the present study, the herbicide pendimethalin was one of the key active substances determining the total value of the FETP impact (Parajuli et al., 2017).

Among the active substances applied in winter wheat, isoproturon (constituting $46.5 \%$ of this indicator value) had the largest contribution to the value of the HTP cancer impact; in sugar beet it was the fungicide flusilazole $(44.9 \%)$ and in winter rape - the fungicide tebuconazole (90.6\%) (Fig. 5).

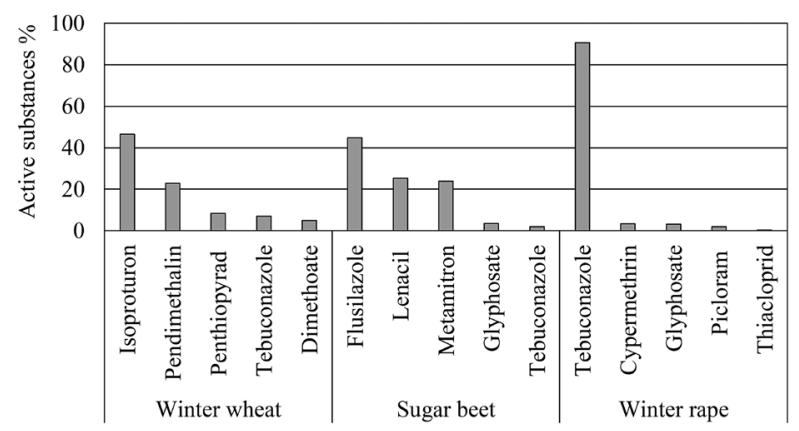

Figure 5. Percentage share of most toxic active substances with the largest contribution to the human toxicity potential (HTP) for carcinogenic effect of chemical protection in the analysed agricultural crops (mean for 2012-2015)

Regarding the HTP for non-carcinogenic effect, the largest contribution to the overall value of this indicator in the case of winter wheat resulted from the application of the herbicide diflufenican (32.6\%), in sugar beet - lenacil $(53.6 \%)$ and in winter rape - chlorpyrifos (64.8\%) (Fig. 6).

As indicated results of our study, the chlorpyrifos had the greatest contribution to the potential impact on human health and the FETP impact in chemical protection of winter rape. Likewise, this substance had the greatest potential toxicity to humans in the production of maize in the Midwestern United States (Xue et al., 2015). Nordborg et al. (2014) noted that chlorpyrifos was the most hazardous substance for freshwater ecosystems, 


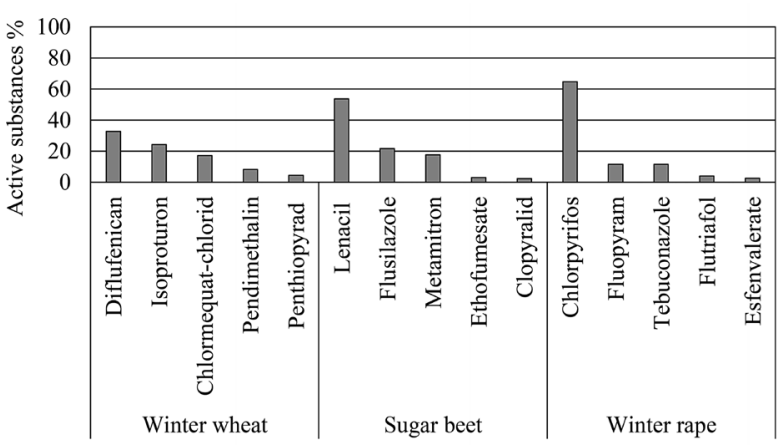

Figure 6. Percentage share of most toxic active substances with the largest contribution to the human toxicity potential (HTP) for non-carcinogenic effect of chemical protection in the analysed agricultural crops (mean for 2012-2015)

followed by the herbicide atrazine in maize protection. Their study showed that high value of the FETP impact in winter rape depended mainly on the use of the insecticide beta-cyfluthrin and the herbicide dimethenamid-P. They also demonstrated that the use of the fungicide chlorothalonil in winter wheat was very toxic to aquatic organisms.

The LCA method results may vary significantly depending on the boundaries and the functional unit adopted for the examined system (Nordborg et al., 2016). In assessing the value of the analysed indicators of potential toxicity for the chemical protection of a given plant across the years and between the species of cultivated plants, their variability is high (Berthoud et al., 2011; Yang, Suh, 2015). This is related to the use of various active substances, characterized by a very different level of toxicity and different values of characterization coefficients (Renaud-Gentié et al., 2015).

In plant production, hazards resulting from the application of PPPs should be taken into account. Recognition of the potential impact of chemical plant protection is of great importance to counteract its negative effects. Toxicity of active substances results mainly from their physico-chemical properties and emissivity. In order to reduce the emissions from PPPs and thus limit potential threats to health and the environment, it is important to choose proper PPPs and technology for their application. The analysis of the results based on the life cycle assessment and toxicity potential impacts on human health and the environment is a key factor in decision making for crop production to become more environmentally friendly.

\section{Conclusion}

The study examined the freshwater ecotoxicity and human toxicity potential (FETP and HTP) impacts for three agricultural crops (winter wheat, sugar beet and winter rape) in relation to the use of different plant protection products (PPPs). It was shown that the main routes for active substances emitted were leaching and surface runoff. Emissions to the air and groundwater were of minor importance. The combination of models PestLCI 2.08 and USEtox 2.02 allowed to obtain the characterization factors for active substances necessary for calculation of potential impacts of active substances on the freshwater environment and human health.
It was found that the FETP impacts from PPPs used were not varied significantly among the analysed agricultural crops. The results showed that the impacts of crop protection were markedly influenced by the choice of active substances with different characterization factors for ecotoxicity. Given the importance of chemical pollution problem in aquatic ecosystems, drawing detail conclusions on the ecotoxicity impacts would require wider scope of data for active substances. Sugar beet had statistically higher value of the HTP impact compared to winter wheat and winter rape. This high impact could primarily result from high intensity level of chemical protection. More comprehensive assessments of FETP and HTP impacts are needed by including a wider spectrum of active substances and levels of PPPs consumption.

\section{Acknowledgements}

The authors thank Maria Nordborg for valuable comments on the interpretation of freshwater ecotoxicity.

Received 03012019

Accepted 17012020

\section{References}

1. Berthoud A., Maupu P., Huet C., Poupart A. 2011. Assessing freshwater ecotoxicity of agricultural products in life cycle assessment (LCA): a case study of wheat using French agricultural practices databases and USEtox model. International Journal of Life Cycle Assessment, 16 (8): 841-847.

https://doi.org/10.1007/s11367-011-0321-7

2. Birkved M., Hauschild M. Z. 2006. PestLCI - a model for estimating field emissions of pesticides in agricultural LCA. Ecological Modelling, 198 (3-4): 433-451.

https://doi.org/10.1016/j.ecolmodel.2006.05.035

3. Brentrup F., Küsters J., Kuhlmann H., Lammel J. 2004. Environmental impact assessment of agricultural production systems using the life cycle assessment methodology. I. Theoretical concept of a LCA method tailored to crop production. European Journal of Agronomy, 20: 247-264. https://doi.org/10.1016/S1161-0301(03)00024-8

4. Caffrey K. R., Veal M. W. 2013. Conducting an agricultural life cycle assessment: challenges and perspectives. Scientific World Journal, 2013: 472431. https://doi.org/10.1155/2013/472431

5. Dijkman T. J., Birkved M., Hauschild M. 2012. PestLCI 2.0: a second generation model for estimating emissions of pesticides from arable land in LCA. International Journal of Life Cycle Assessment, 17 (8): 973-986. https://doi.org/10.1007/s11367-012-0439-2

6. EPI Suite. 2018. EPI Suite ${ }^{\mathrm{TM}}$ - Estimation Program Interface. United States Environmental Protection Agency, USA. https://www.epa.gov/tsca-screening-tools/episuitetm-estimation-program-interface

7. EU Pesticides Database. 2018. European Commission. http://ec.europa.eu/sanco_pesticides/public

8. Fantin V., Righi S., Rondini I., Masoni P. 2017. Environmental assessment of wheat and maize production in an Italian farmers' cooperative. Journal of Cleaner Production, 140: 631-643. https://doi.org/10.1016/j.jclepro.2016.06.136

9. Fantke P., Jolliet O. 2016. Life cycle human health impacts of 875 pesticides. International Journal of Life Cycle Assessment, 21 (5): 722-733.

https://doi.org/10.1007/s11367-015-0910-y 
10. Garavini G., Zamagni A., Porta P. L., Masoni P., Facibeni G., Fantin V., Righi S. 2015. Pesticide emissions in the Environmental Product Footprint - lessons learnt from refined sugar from sugar beet. International Conference LCA for "Feeding the planet and energy for life" EXPO 2015, p. 45-48.

11. Hauschild M. Z., McKone T. E., van de Meent D., Huijbregts M., Margni M., Rosenbaum R., Jolliet O., Fantke P. 2016. USEtox ${ }^{\circledR}$ 2.02. The UNEP/SETAC scientific consensus model for characterizing human and ecotoxicological impacts of chemical emissions in life cycle impact assessment. https://usetox.org/model/ download/usetox 2.0

12. Henderson A. D., Hauschild M. Z., Van de Meent D., Huijbregts M. A. J., Larsen H. F., Margni M., McKone T. E., Payet J., Rosenbaum R. K., Jolliet O. 2011. USEtox fate and ecotoxicity factors for comparative assessment of toxic emissions in life cycle analysis: sensitivity to key chemical properties. International Journal of Life Cycle Assessment, 16 (8): 701-709.

https://doi.org/10.1007/s11367-011-0294-6

13. Holka M. 2017. Environmental impact assessment of chemical plant protection in intensive crop production. Journal of Central European Agriculture, 18 (3): 529-541. https://doi.org/10.5513/JCEA01/18.3.1926

14. Houdart M., Tixier P., Lassoudière A., Saudubray F. 2009. Assessing pesticide pollution risk: from field to watershed. Agronomy for Sustainable Development, 29 (2): 321-327. https://doi.org/10.1051/agro:2008042

15. Kim K.-H., Kabir E., Jahan S. A. 2017. Exposure to pesticides and the associated human health effects. Science of the Total Environment, 575: 525-535. https://doi.org/10.1016/j.scitotenv.2016.09.009

16. Kot-Wasik A., Dąbrowska D., Namieśnik J. 2003. Degradation of organic compounds in the environment. Namieśnik J. et al. (eds). New horizons and challenges in analytics and environmental monitoring. CEEAM, chapter 33, p. 700-722 (in Polish).

17. Mahmood I., Imadi S. R., Shazadi K., Gul A., Hakeem K. R. 2016. Effects of pesticides on environment. Hakeem K. R. et al. (eds). Plant, soil and microbes. Springer, p. 253-269. https://doi.org/10.1007/978-3-319-27455-3_13

18. Margni M., Rossier D., Crettaz P., Jolliet O. 2002. Life cycle impact assessment of pesticides on human health and ecosystems. Agriculture, Ecosystems and Environment, 93: 379-392. https://doi.org/10.1016/S0167-8809(01)00336-X

19. Nemecek T., Kägi T. 2007. Life cycle inventories of agricultural production systems. Agroscope Taenikon Research Station ART, Swiss Centre for Life Cycle Inventories.

20. Neto B., Dias A. C., Machado M. 2012. Life cycle assessment of the supply chain of a Portuguese wine: from viticulture to distribution. International Journal of Life Cycle Assessment, 18 (3): 590-602.

https://doi.org/10.1007/s11367-012-0518-4

21. Nordborg M., Cederberg Ch., Berndes G. 2014. Modeling potential freshwater ecotoxicity impacts due to pesticide use in biofuel feedstock production: the cases of maize, rapeseed, salix, soybean, sugar cane, and wheat. Environmental Science and Technology, 48 (19): 11379-11388. https://doi.org/10.1021/es502497p

22. Nordborg M., Davis J., Cederberg C., Sonesson U., Berndes G. 2016. Assessing potential pesticide-related ecotoxicity impacts of food products across different functional units. $10^{\text {th }}$ International Conference on Life Cycle Assessment of Food. Dublin, Ireland, p. 1-6.
23. Parajuli R., Sillebak Kristensen I., Knudsen M., Mogensen L., Corona A., Birkved M., Peña N., Graversgaard M., Dalgaard T. 2017. Environmental life cycle assessments of producing maize, grass-clover, ryegrass and winter wheat straw for biorefinery. Journal of Cleaner Production, 142: 3859-3871.

https://doi.org/10.1016/j.jclepro.2016.10.076

24. Parrón T., Requena M., Hernández A. F., Alarcón R. 2014. Environmental exposure to pesticides and cancer risk in multiple human organ systems. Toxicology Letters, 230 (2): 157-165. https://doi.org/10.1016/j.toxlet.2013.11.009

25. PPDB. 2018. The Pesticide Properties Database (PPDB). University of Hertfordshire, UK. http://sitem.herts.ac.uk/ aeru/ppdb/index.htm

26. Renaud-Gentié Ch., Dijkman T. J., Bjørn A., Birkved M. 2015. Pesticide emission modelling and freshwater ecotoxicity assessment for grapevine LCA: adaptation of PestLCI 2.0 to viticulture. International Journal of Life Cycle Assessment, 20: 1528-1543. https://doi.org/10.1007/s11367-015-0949-9

27. Rosenbaum R. K., Bachmann T. M., Swirsky Gold L., Huijbregts M. A. J., Jolliet O., Juraske R., Koehler A., Larsen H. F., MacLeod M., Margni M., McKone T. E., Payet J., Schuhmacher M., Van de Meent D., Hauschild M. Z. 2008. USEtox - the UNEP-SETAC toxicity model: recommended characterisation factors for human toxicity and freshwater ecotoxicity in Life Cycle Impact Assessment. The International Journal of Life Cycle Assessment, 13 (7): 532-546. https://doi.org/10.1007/s11367-008-0038-4

28. Rosenbaum R. K., Huijbregts M. A. J., Henderson A. D., Margni M., McKone T.E., MeentD. van de, Hauschild M. Z., Shaked S., Li D. S., Gold L. S., Jolliet O. 2011. USEtox human exposure and toxicity factors for comparative assessment of toxic emissions in life cycle analysis: sensitivity to key chemical properties. International Journal of Life Cycle Assessment, 16 (8): 710-727. https://doi.org/10.1007/s11367-011-0316-4

29. Rosenbaum R. K., Anton A., Bengoa X., Bjørn A., Brain R., Bulle C., Cosme N., Dijkman T., Fantke P., Felix M., Geoghegan T., Gottesbüren B., Hammer C., Humbert S., Jolliet O., Juraske R., Lewis F., Maxime D., Nemecek T., Payet J., Räsänen K., Roux P., Schau E., Sourisseau S., Van Zelm R., von Streit B., Wallman M. 2015. The Glasgow consensus on the delineation between pesticide emission inventory and impact assessment for LCA. International Journal of Life Cycle Assessment, 20 (6): 765-776. https://doi.org/10.1007/s11367-015-0871-1

30. Saouter E., Aschberger K., Fantke P., Hauschild M. Z., Bopp S. K., Kienzler A., Paini A., Pant R., Secchi M., Sala S. 2017. Improving substance information in USEtox ${ }^{\circledR}$, part 1: discussion on data and approaches for estimating freshwater ecotoxicity effect factors. Environmental Toxicology and Chemistry, 36 (12): 3450-3462. https://doi.org/10.1002/etc.3889

31. Van Zelm R., Larrey-Lassale P., Roux P. 2014. Bridging the gap between life cycle inventory and impact assessment for toxicological assessment of pesticides used in crop production. Chemosphere, 100: 175-181. https://doi.org/10.1016/j.chemosphere.2013.11.037

32. Xue X., Hawkins T., Ingwersen W., Smith R. 2015. Demonstrating an approach for including pesticide use in Life Cycle Assessment: estimating human and ecosystem toxicity of pesticide use in Midwest corn farming. International Journal of Life Cycle Assessment, 20 (8): $1117-1126$.

https://doi.org/10.1007/s11367-015-0902-y 
33. Yang Y., Suh S. 2015. Changes in environmental impacts of major crops in the US. Environmental Research Letters, 10: 094016.

https://doi.org/10.1088/1748-9326/10/9/094016
34. Żak A. 2016. Plant protection products versus changes in the natural environment and their impact on the human health. Problems of Agricultural Economics, 1 (346): 153-162.

ISSN 1392-3196 / e-ISSN 2335-8947

Zemdirbyste-Agriculture, vol. 107, No. 2 (2020), p. 131-138

DOI 10.13080/z-a.2020.107.017

\title{
Žieminių kviečių, cukrinių runkelių ir žieminių rapsų cheminės apsaugos produktų toksiškumo ịtaka vandens ekosistemai ir žmonèms
}

\author{
M. Holka, J. Bieńkowski \\ Lenkijos mokslų akademijos Žemès ūkio ir miško aplinkos institutas
}

\section{Santrauka}

Tyrimo tikslas - ịvertinti galimą augalų apsaugos produktų toksiškumą vandens ekosistemai ir žmonėms. Tyrimo metu analizuota žieminių kviečiu (Triticum aestivum L.), cukriniu runkeliu (Beta vulgaris L.) ir žieminiu rapsų (Brassica napus L.) cheminè apsauga, naudota Trzebiny ūkyje, Wielkopolska vaivadijoje, Lenkijoje. Emisijos i aplinką maršrutai ir kiekiai buvo nustatyti modeliu PestLCI 2.08. Gauti rezultatai sudare tyrimų, kurių metu taikytas gyvavimo ciklo vertinimo metodas, aprašą. Modeliu USEtox 2.02 buvo vertintas ekotoksiškumo gèliesiems vandenims potencialas ir toksiškumas žmonėms, ịskaitant kancerogeninị ir nekancerogeninị poveikị. Iš analizuotų pasėlių didžiausias veikliujų medžiagų suvartojimas nustatytas cukrinių runkeliu $\left(7,43 \mathrm{~kg} \mathrm{ha}^{-1}\right)$, mažesnis - žieminių kviečių $\left(2,64 \mathrm{~kg} \mathrm{ha}^{-1}\right)$, mažiausias - žieminių rapsų $\left(2,16 \mathrm{~kg} \mathrm{ha}^{-1}\right)$ apsaugai. İvertinus su augalų apsaugos produktais ị aplinką patenkančių teršalų kiekị nustatyta, kad didžiausias kiekis veikliụjų medžiagų pateko per išplovimą ir paviršinį nuotèkị (vidutiniškai $91,7 \%$ bendros emisijos). Emisijos į orą ir gruntinius vandenis buvo mažesnès - vidutiniškai 7,7 ir 0,6 \%. Tarp tirtų augalų rūšių reikšmingų ekotoksiškumo gẻlam vandeniui skirtumu nebuvo nustatyta. Didžiausia pavoju žmoniu (h) sveikatai sukèlè cheminè cukriniu runkeliu apsauga (1.7E - 05 lyginamasis toksiškas vienetas $\left.(\mathrm{CTU}) \mathrm{h} \mathrm{ha}^{-1}\right)$. Mažiausia toksiškumo žmonėms galimo poveikio reikšmė buvo nustatyta saugant žieminius rapsus (3.3E - 06 CTUh ha-1).

Tyrimo rezultatai parodè, kad bendras ekotoksiškumo gèlam vandeniui ir toksiškumo žmonèms poveikis buvo susijęs su tam tikrų veikliujų medžiagų fizikinėmis bei cheminėmis savybėmis ir toksiškumu. Siekiant išsamiau ịvertinti galimą augalų apsaugos produktų poveikị, reikia tirti kuo įvairesnį veikliụjų medžiagų asortimentą.

Reikšminiai žodžiai: ekotoksiškumas gèlam vandeniui, teršalų išmetimas i aplinką, toksiškumas žmonėms, veikliosios medžiagos. 